\title{
Understanding the Belt and Road Initiative under Contemporary International Law"
}

\section{Zewei Yang**}

The Belt and Road Initiative (BRI) is a new model of international cooperation and new platform for global governance under contemporary international law. The Initiative will promote basic principles of international law, playing the mediating role of preventing disputes and resolving various risks in the process of establishing a new pattern of global governance. The Initiative is in line with the new trend of international cooperation and development in the 21st century, representing a new round of the process of reforming international political economy. It is a useful attempt to enhance China's contribution to economic co-prosperity and political stability among the countries along the Belt and Road. This paper tries to understand the BRI under contemporary international law. Part two will discuss the status of the BRI. Part three will investigate the influence of the BRI. Part four will analyze the function of contemporary international law for co-building the Belt and Road.

Keywords: BRI, Contemporary International Law, Global Governance, International Cooperation

* This article is a part of the results of the Major Project of National Social Science Foundation of China, "A Research on the'Belt and Road' Initiative and Its International Rules System" (Project No. 18VDL002). All the websites cited in this article were last accessed on August 8, 2019.

** Luojia Distinguished Professor of International Law Institute, China Institute of Boundary and Ocean Studies, and Collaborative Innovation Center for Territorial Sovereignty and Maritime Rights at Wuhan University. A.B. (Hunan Normal Univ.), M.A./Ph.D.(Wuhan). ORCID: http:// orcid.org/0000-0001-9937-2741. The author may be contacted at: fxyyzw@whu.edu.cn/Address: Luojia Hill, Wuhan, Hubei Province, 430072, P.R. China. 


\section{INTRODUCTION}

Since 2013, the Belt and Road Initiative (hereinafter The Initiative: "BRI") has made remarkable achievements and demonstrated extensive international influence. Investment as well as economic and trade cooperation between China and countries along the Belt and Road have significantly increased. Trade in goods has exceeded USD 6 trillion; investment to the countries along the Belt and Road has exceeded USD 90 billion; 82 overseas economic and trade cooperation zones have been established; 244,000 employment posts have been created for local citizens; and more than 13,000 trains of China Railway Express have been put into operation. ${ }^{1}$ Additionally, by the end of March 2019, China had signed 173 inter-governmental cooperation documents on co-building the Belt and Road with 125 countries and 29 international organizations. ${ }^{2}$ Notably, in March 2017, the United Nations Security Council referred to China's BRI in Resolution 2344 on "the situation in Afghanistan" for the first time. ${ }^{3}$ President Xi Jinping addressed: "Co-building 'the Belt and Road' is becoming China solution to participate in global open cooperation, to improve the global economic governance system, to encourage global common development and prosperity, and to promote the construction of a community with a shared future for mankind." Therefore, it is of great theoretical value and practical significance to discuss the influence of the BRI on the development of contemporary international law and to expound its supporting function in co-building the Belt and Road.

This paper is divided into five parts including the Introduction and Conclusion. Part two will discuss the status of the BRI in contemporary international law. Part three will investigate the influence of the BRI on contemporary international law. Part four will analyze the function of contemporary international law in co-building the Belt and Road.

\section{The BRI IN CONTEMPORARY INTERNATIONAL LAW}

Up to now, the Chinese government has successively issued a series of important legal documents on the BRI, such as: Vision and Action for Co-building the Silk Road Economic Belt and the 21st Century Maritime Silk Road (March 28, 2015); 
Educational Action for Co-building the Belt and Road (July 13, 2016); Plans for Construction and Development of China Railway Express 2016-2020 (October 24, 2016); Action Plans for Cultural Development of the Belt and Road by Ministry of Culture 2016-2020 (March 1, 2017); Guidance on Promoting Green Belt and Road Construction (May 8, 2017); Co-building the Belt and Road: Concept Practice and China's contribution (May 10, 2017); Vision and Action for the Agricultural Cooperation in the Belt and Road Construction (May 13, 2017); Guidance on Financing of the Belt and Road (May 16, 2017); Vision and Action for Cobuilding the Silk Road Economic Belt and Energy Cooperation of the 21st Century Maritime Silk Road (May 16, 2017); Vision for Maritime Cooperation in the Belt and Road Construction (June 20, 2017); Action Plan of Standard Connectivity for Co-building the Belt and Road 2018-2020 (January 11, 2018); and The BRI Progress, Contributions and Prospects (April 24, 2019).

All these documents show that the BRI is a new type of international cooperation, new platform for global governance, and a new dimension for cross-regional international cooperation. International law is thus a key factor in operating the BRI.

\section{A. New Type of International Cooperation}

As an intelligent design which promotes balanced, inclusive, and sustainable global development and common prosperity of mankind, the BRI is undoubtedly a new type of international cooperation.

1. The goal of the BRI is to achieve deeper regional and global cooperation. Conforming to the basic interests of China and other countries along the Belt and Road, the Initiative upholds the principles of "open cooperation, harmony and inclusiveness, market operation, and mutual benefit." Its purpose is:

promoting orderly and free flow of economic factors, efficient allocation of resources, and deep integration of markets, encouraging countries along the Belt and Road to achieve the coordination of economic policy; the development of regional cooperation on a larger scale, at a higher level and in a greater depth; and co-building an open, inclusive, balanced and mutually beneficial regional economic cooperation architecture. 
The BRI is making full use of existing international cooperation mechanisms for bilateral, regional, and multilateral cooperation. Firstly, bilateral dialogue is the main channel for policy communication in the BRI. China and relevant countries have been strengthening the role of bilateral cooperation mechanisms to serve the cooperation in key areas of the Belt and Road construction, such as interconnection and interworking, trade and investment, production capacity cooperation, and cultural and educational exchanges.

Secondly, the BRI will play a mediating role ${ }^{6}$ in economic and trade cooperation by hosting large-scale exhibitions such as the China-ASEAN Expo, China-Eurasia Expo, China-Arabian States Expo, China-South Asia Expo, and China-CEEC Investment and Trade Expo.

Finally, the BRI will strengthen the role of multilateral cooperation mechanisms by existing multilateral cooperation mechanisms such as Shanghai Cooperation Organization (SCO), China-ASEAN "10+1," Asia-Pacific Economic Cooperation (APEC), the Asia-Europe Meeting (ASEM), Asian Cooperation Dialogue (ACD), Conference on Interaction and Confidence-Building Measures in Asia (CICA), China-Arab Cooperation Forum, China-GCC strategic Dialogue, Greater Mekong Subregion (GMS) Economic Cooperation, and Central Asia Region Economic Cooperation (CAREC). ${ }^{7}$

The BRI maintains pluralistic and open cooperation. Although the BRI is proposed by China, "China will not play geopolitical game; will not engage with a closed exclusive circle; and will not override other countries or force others to buy or sell." ${ }^{\prime 8}$ Therefore, the construction model of the BRI focuses on goal coordination and policy communication, insists on the principle of "open cooperation," and welcomes all countries and international organizations to participate to let the fruits of joint construction benefit more areas. ${ }^{9}$ As of December 2017, China has signed more than 60 treaties such as the judicial assistance treaty, extradition treaty, and treaty on combating the "three forces;" more than 50 agreements on avoidance of double taxation; more than 50 bilateral investment protection agreements; more than 60 bilateral civil aviation agreements; and nearly 30 memoranda of understanding on bilateral bank supervision with countries along the Belt and Road. ${ }^{10}$ In conclusion, the BRI is an "active exploration of new models of international cooperation and global governance."11 


\section{B. New Platform for Global Governance}

The BRI is China's idea and plan for global governance. For the past few years, China has actively pursued multilateralism following the trend of globalization and actively participated in and guided global governance through the UN, G20, APEC, ASEAN 10+3, SCO, and BRICS. In order to promote the BRI by upholding the concept of community with a shared future for mankind and sticking to the principles of "joint discussion, co-building, and sharing," China has established a global network of partnerships in all fields, including the Asian Infrastructure Investment Bank (“AIIB"), which addressed many global challenges. The BRI demonstrates China's responsibility to promote the development of a fair, just, and equitable global governance system as the largest developing country and the second largest economy in the world. ${ }^{12}$

The BRI designs innovative architecture and models of global governance. At present, new challenges confront globalization, while the innovation in global governance mechanisms is abating. However, the BRI is devoted to "building a new system of global governance, where countries, whether big or small, can all participate together, pursue mutual benefit and complementary advantages, support increasing the voice of developing countries in the global governance system to realize the gradual transformation of global governance from 'western governance' to 'joint governance of the east and the west,","13 thereby promoting peaceful cooperation and common development in the world. Its process is public, transparent, and open. In addition, the BRI surpasses the traditional 'center-edge' governance model to adopt the " $1+\mathrm{N}$ convener model" initiated by China, adjusts the ways of cooperation according to mutual wills, and finally forms a multilateral planar cooperation network. ${ }^{14}$

The BRI has become the most popular global public product. It has promoted the common development of mankind and coordinated the interests and needs of the Belt and Road region and even all countries in the world. Moreover, the BRI has become one of the most important platforms for global governance, as it does not set ideological boundaries, engage in zero-sum games, or interfere in internal affairs of other countries. Shin Kawajima, a professor at the University of Tokyo points out:

One of the reasons why the Chinese Belt and Road Initiative has been of such 
significance for the huge area that stretches from Eurasia to Africa to the Pacific was that support and investment from developed countries, especially the United States, had been declining dramatically, and moreover tended to come attached with burdensome requirements associated with democratization and human rights. The infrastructure demand in Africa and the Asia-Pacific region is enormous. Funds from developed countries, the Asian Development Bank, and the World Bank are not sufficient to meet this demand. ${ }^{15}$

\section{New Dimension for Cross-Regional Cooperation}

The BRI going through five continents connecting four oceans. Firstly, the Silk Road Economic Belt brings together China and Europe (the regions around the Baltic Sea) via Central Asia, Russia, the Persian Gulf, and the Mediterranean Sea via Central and Western Asia, and Southeast Asia, South Asia and the Indian Ocean.

Secondly, the 21st Century Maritime Silk Road covers the South China Sea and the Indian Ocean region and extends to Europe and the South Pacific.

Finally, the territorial scope of the BRI is continuously expanding. ${ }^{16}$ In 2018, a "Polar Silk Road" was constructed across the Arctic Ocean ${ }^{17}$ and Panama became the first Latin American country to cooperate with the BRI. ${ }^{18}$

The BRI is not only a regional economic cooperation, but also an intended global governance system. On the one hand, the international economic cooperation proposed in the BRI includes six major international economic cooperation corridors: the New Eurasia Continental Bridge, the China-Russia-Mongolia Economic Corridor, the China-Central Asia-Western Asia Economic Corridor, the China-Indochina Peninsula Economic Corridor, the China-Pakistan Economic Corridor, and the BangladeshChina-India-Myanmar Economic Corridor.

On the other hand, in the practice of advocating for the BRI, China has not only signed many agreements with countries along the Belt and Road, ${ }^{19}$ but also paid attention to deepening cooperation with relevant international organizations under the framework of co-building the Belt and Road. It signed legal documents on cobuilding the Belt and Road with international organizations such as the United Nations Economic and Social Commission for Asia and the Pacific ("UNESCAP"), the United Nations Development Program ("UNDP"), and the World Health Organization ("WHO”). 


\section{INFLUENCE OF THE BRI ON CONTEMPORARY INTERNATIONAL LAW}

\section{A. The BRI Develops Basic Principles of International Law}

The BRI not only adds new content, but also deepens the connotation of the existing principles of international law.

The BRI adds new contents to the basic principles of international law, such as sovereign equality, non-intervention in internal affairs, the prohibition of the threat or use of force, and the principle of peaceful resolutions of international disp utes. The BRI always upholds the principles of "joint discussion, co-building, and sharing" 21 as it is put forward. The principles of "joint discussion, co-building, and sharing" have been contained in 170 inter-governmental cooperation documents on co-building the Belt and Road that China has signed with countries along the Belt and Road and relevant international organizations. The principles of "joint discussion, co-building, and sharing" may have the same origin of the basic principles of international law as the UN Charter. It also has been recognized by the international community having universal binding force and being applicable to all fields of international law. These principles therefore become the new content of the basic principles of international law. ${ }^{22}$

The BRI promotes the principle of sovereign equality, which emphasizes that all states are fundamentally equal under international law. The BRI not only adheres to harmony and inclusiveness, but also respects the choice of development roads and patterns of all countries. It further advocates tolerance strengthens dialogue among civilizations. Seeking common ground while preserving differences, the BRI embraces mutuality, co-existence, and common prosperity. It undoubtedly enriches the connotation of sovereign equality.

The BRI realizes the concrete forms of international cooperation. International cooperation, as one of the basic principles of international law, has various concrete forms. However, as the BRI is an open and inclusive cooperation platform and a global public product jointly created by all parties, its participating countries adhere to the principles of "joint discussion, co-building, and sharing." They carry forward the Silk Road spirit of "peaceful cooperation, openness and inclusiveness, mutual learning, and mutual benefit," across different regions, different stages of development, and different civilizations for promoting and 
building the Belt and Road. They recognize market operations, follow the laws of the market and internationally accepted trade rules, adhere to the principle of mutual benefit, and accommodate the interests of all parties to further enrich the concrete forms of the principles of international cooperation. ${ }^{23}$

The BRI further seeks peaceful resolutions for international disputes. In 2018, the Supreme People's Court of the People's Republic of China set up "the First International Commercial Court" in Shenzhen city of Guangdong province and "the Second International Commercial Court" in Xi' an city of Shanxi province. Meanwhile, the Supreme People's Court has also taken the lead in setting up the "International Commercial Expert Committee" composed of 32 Chinese and foreign experts. The establishment of "International Commercial Court" and "International Commercial Expert Committee" draws on the experience with the useful practices of the current international dispute settlement mechanism as well as embodies the principle of diversified dispute settlement methods, which help to fairly, efficiently, and conveniently resolve the cross-border commercial disputes arising from the process of building Belt and Road. ${ }^{24}$

\section{B. The BRI Promotes the International Transit Transport System}

The interconnection and interworking of infrastructure are the key aims of the Belt and Road construction. ${ }^{25}$ Therefore, the BRI helps to further improve the international transit transport system.

The BRI is always making 'hard connectivity' such as infrastructure for cooperation. The main framework of the BRI includes 'Six Roads' and 'Multiple Ports.' 'Six Roads' refers to railway, highway, shipping, aviation, pipeline, and the space-integrated information network, which are the main contents of infrastructure connectivity. Meanwhile, 'Multiple Ports' indicates a number of cooperative ports to ensure the safety and smooth passage of major sea transport routes, which further boosts maritime cooperation by building a number of important ports and node cities in countries along the Belt and Road. ${ }^{26}$ Especially the China Railway Express started running in March 2011, according to the mechanism of 'Six Uniformities. ${ }^{27}$ It is an important carrier to deepen China's economic and trade cooperation with countries along the Belt and Road and an important method to promote the Belt and Road construction. 
The BRI promotes the harmonization of rules and systems for interconnection and interworking among countries and enhances 'soft connectivity.' In order to further promote international transit and improve transportation systems, China has signed 16 bilateral and multilateral transport facilitation agreements, including the agreement among the governments of the SCO Member States on the International Road Transport Facilitation and the Intergovernmental Agreement on International Road Transport along the Asian Highway Network among 15 countries through the Belt and Road. China has also facilitated measures such as Agreement to Facilitate the Cross-border Movement of Goods and Persons in the Greater Mekong Subregion and opened 356 international road transport routes through 73 land ports. Moreover, China has signed 38 bilateral and regional maritime agreements with 47 countries along the Belt and Road. It has also signed bilateral intergovernmental air transport agreements with 62 countries to allow for direct civil aviation flights. ${ }^{28}$ In addition, the related departments of the Chinese government have also issued Opinions on Accelerating the Implementation of the BRI to Promote the International Road Transport Facilitation to encourage the participating parties of the Belt and Road to strengthen the coordination and cooperation on rules pertaining to Visa and customs clearance so as to facilitate the cross-border movement of persons and goods.

\section{The BRI Enriches the Mode of Implementation of International Law}

There are two modes of implementing international law in China: direct application (incorporation) and indirect application (transformation). The BRI, as a new platform for open global governance, focuses on the connection with the development projects of international organizations and remains committed to bilateral connection with the countries along the Belt and Road, in order to innovate a mode of implementation of international law.

In 2015, the UN General Assembly passed Transforming Our World: The 2030 Agenda for Sustainable Development, clearly proposing 17 sustainable development goals and 169 related, specific targets. ${ }^{29}$ In the same year, the African Union proposed Agenda 2063 to accelerate industrialization and agricultural modernization of Africa, with addressing the problems of undeveloped infrastructure construction and insufficient human resources identified as the top priority. ${ }^{30}$ In this regard, the September 2018 Beijing Summit of the 
Forum on China-Africa Cooperation, in which China reaffirmed its support for African countries participating in the co-construction of the Belt and Road, strengthened its connection with Agenda 2063, and facilitated the connection of the Agenda 2030 for Sustainable Development of the United Nations with African development strategy. ${ }^{31}$ In addition, China also adheres to the connection of the BRI with other multilateral cooperation mechanisms such as the European Investment Plan, the Master Plan 2025 on ASEAN Connectivity, the APEC Connectivity Blueprint, Asia-Europe Connectivity, and Greater Mekong Sub-region Economic Cooperation Program. ${ }^{32}$

There have been numerous initiatives to connect the BRI with the countries along the Belt and Road. The countries along the Belt and Road have proposed various development strategies in the light of their own national conditions. Examples of these concepts include, Indonesia's "Global Ocean Fulcrum," Laos' "Landlocked Country into a Land-united Country," Vietnam's "Two Corridors and One Circle," South Korea's "Eurasia Initiative," Kazakhstan's "Bright Road," Pakistan's "Vision 2025," Saudi Arabia's "Western Plan," Mongolia's "Prairie Road," Turkey's "Central Corridor," Poland's "Responsible Development Strategy," Serbia's "Re-industrialization," and Panama's "National Logistics Strategy for 2030." As these development strategies are highly consistent with the BRI, China strives to promote the implementation together with those countries, seeking cooperation with an equal division of responsibilities. ${ }^{33}$

\section{The BRI Strengthens the International Development Aid System}

The BRI gives some new meaning to 'development.' In this context, 'development' is of supreme political importance for developing countries. As for China, 'development' assumes the meaning of the "renaissance of civilization."

The BRI provides a more unique form of international development aid. For example, as part of the BRI, China has provided funding for more than 3,000 major infrastructure projects in Africa and has offered loans of at least USD 86 billion to many African countries. China has invested USD 4 billion to build a railway from Djibouti to Addis Ababa, Ethiopia, and built Africa's largest free trade zone in Djibouti at a cost of USD 3.5 billion. In addition, China has built a cement plant in Zambia at a cost of USD 548 million. China has offered African leaders a unique 'menu' featuring a loan, development aid, and infrastructure 
financing. Furthermore, China pursues the principle of non-interference in internal affairs of other countries. ${ }^{34}$

The international development aid in the context of co-building the Belt and Road emphasizes mutual benefit. For example, Africa has not only a wealth of resources, a large population, a vast market, and a huge potential for development, but it also has an undeveloped economy and a lack of capital, technology, and development experience. Conversely, China has a relatively strong economy, various and exceptional talents, extensive equipment and technologies, and successful experience in economic construction, but faces questions such as a shortage of resources and intense domestic market competition. Therefore, China and Africa can complement each other using their respective resource endowments and build the Belt and Road together while mutually benefitting. On the one hand, Africa can provide the guarantee of raw materials, markets, and investment sites for the sustainable development of China's economy, ${ }^{35}$ while, on the other hand, Africa can gain access to finance, technology, and experience with development, diversify its raw material exports, increase its autonomy, and develop its own resources. ${ }^{36}$

\section{E. The BRI Affects the Law of Diplomatic Relations}

Diplomatic relations refers to the continuous foreign relations officially maintained between countries. ${ }^{37}$ In other words, only countries that are essential players in international law can establish and develop diplomatic relations. However, in the process of advocating for the BRI, China attaches great importance to the important role of cooperation between cities and regions. ${ }^{38}$ Therefore, the BRI affects the development of the law of diplomatic relations to some extent. For example, in October 2018, the Chinese government bypassed the Australian federal government and signed a memorandum of understanding with the state of Victoria on the Belt and Road cooperation. It not only overcame the principle that the external relations of cities and regions are consistent with the foreign policies of the national government, but also is, to some extent, a new breakthrough in foreign relations law.

In addition, the Chinese government grants cities and provinces a central role in planning and implementing the BRI. Cities and regions along the Belt and Road in China make plans based on their own conditions, hoping to develop 
international cooperation in the larger framework of the BRI. For instance, the Hunan province has established a special fund for the Belt and Road.

In recognition of this, some European scholars have suggested that European countries should take a pragmatic approach to the BRI and promote cooperation between cities and regions as the key to the cooperation with China. Cities and regions in Europe should work with those in China to cultivate a more innovative relationship that involves the coordination of national governments. ${ }^{39}$

\section{F. The BRI Breeds and Generates the Inclusiveness of International Law}

'Inclusiveness' is one of the ideas put forward in the United Nations Millennium Development Goals. ${ }^{40}$ In 2011, a Chinese leader clearly expounded the concept of 'Inclusive Development' at the Boao Forum for Asia. The BRI will promote the generation of Inclusive International Law. ${ }^{41}$

First, 'harmony' and 'inclusiveness' are the principles of co-building the Belt and Road. The BRI advocates tolerance among civilizations, respects all countries' choice of road patterns to develop, strengthens dialogue among civilizations, embraces mutuality, and pursues co-existence and common prosperity.

Secondly, as the BRI is a new platform for international governance, its construction process is inclusive and open to all countries and international organizations.

Finally, the way to co-build the Belt and Road is highly flexible and elastic. It focuses on goal coordination and policy communication rather than prioritizing consistency. China and other countries along the Belt and Road have worked together to formulate a schedule and road map and continuously improve the content and model of cooperation in co-building the Belt and Road. The BRI establishes the "rules and regulations of a new and inclusive globalization era."

\section{G. The BRI Provides New Content to the Global Governance}

As a new model and mechanism of international governance, the BRI adds significantly new content to global governance, in terms of ideas, methods, and specific rules to advance it.

1. Ideas. The BRI inherits the spirit of the ancient Silk Road, adheres to the core ideas of "peaceful cooperation, openness and inclusiveness, mutual learning, and 
mutual benefit" to finally build the Belt and Road to be "the road to peace, the road to prosperity, the road to openness, the road to green, the road to innovation, and the road to civilization., ${ }^{43}$

2. Models and methods. Firstly, the BRI addresses the principle of "joint discussion, co-building, and sharing" and constantly expands the consensus of cooperation among countries along the Belt and Road. Secondly, the BRI lays emphasis on the top-level design and establishes five major directions, including the three major directions of the Silk Road Economic Belt and the two major directions of the 21st Century Maritime Silk Road, as well as the main framework including 'Six Corridors, ${ }^{44}$ 'Six Roads, ${ }^{45}$ 'Multiple Countries,' and 'Multiple Ports. ${ }^{46}$ Finally, the Belt and Road co-construction takes policy communication, infrastructure connectivity, smooth trade, finance integration, and people's collective feelings as the main content of international cooperation.

3. Specific rules. Standardization is an important component of global governance. In order to promote cooperation with respect to standardization, China and other countries along the Belt and Road strengthen the compatibility of technical standards and systems in infrastructure, international production capacity, equipment manufacturing, trade and finance, energy and environment, cultural and educational exchanges, health services, and poverty reduction practices. ${ }^{47}$ This practice of standardization takes into account the actual conditions and development needs on the basis of referring to and incorporating an international standard to promote both "one test, one certificate, and one global mutual accreditation," and "one standard, one certificate, and one regional pass," ${ }^{, 48}$ with respect to certifications and accreditations as well as inspection and quarantine. The Chinese government successively issues a series of legal documents such as Action Plan of Standard Connectivity for Co-building the Belt and Road (20152017), Vision and Action for Jointly Promoting the Services of Certification and Accreditation to the Belt and Road Construction, and Vision and Action for Metrology Cooperation of the Belt and Road. The above practices comply with the trend of "developing international standards for the high-quality infrastructure" under global governance. ${ }^{49}$ 


\section{Mediating the Belt and Road Disputes UNDER INTERNATIONAL LAW}

\section{A. Preventing and Resolving Risks for Co-building the Belt and Road}

From the 'five directions' planned in the top-level design of the BRI, Southeast Asia, Central Asia, the Middle East, and Africa are areas with high levels of terrorism. Therefore, people in these regions are easily exposed to risks that threaten their personal security. Moreover, the BRI has a long implementation period, so that it would inevitably encounter financial and political risks. ${ }^{50}$ However, contemporary international law provides many measures to prevent various risks in the process of co-building the Belt and Road.

1. Existing law. As of the end of 2016, Chinese companies had 56 economic and trade cooperation zones under construction in 20 countries along the Belt and Road, with accumulated investments worth more than USD 18.5 billion. ${ }^{51}$ The following means can be used to prevent the above-mentioned political risk in the process of co-building the Belt and Road. ${ }^{52}$

The first is to utilize the Convention of the Multilateral Investment Guarantee Agency, the World Bank 1985, and the Multilateral Investment Guarantee Agency established in 1988. International practice has shown that the Multilateral Investment Guarantee Agency has obvious advantages in preventing political risks, mediating and settling disputes, and smoothly realizing claims on behalf of others. ${ }^{53}$

The second is the bilateral investment treaties. In terms of protecting and promoting private direct investment activities, signing a bilateral investment treaty is currently the most effective international legal measure. ${ }^{54}$ As of December 2016, China had signed bilateral investment treaties with 104 countries. ${ }^{55}$

The third is the overseas investment insurance funds. China Investment Insurance Fund (USD 40 billion), officially set up in January 2016, has invested in the overseas projects of the Belt and Road to guard against various political risks such as the risks of taxation, foreign exchange, war, and civil strife.

2. Ideal law. On the one hand, early warning systems and a risk prevention and treatment organization promoting the Belt and Road implementation should be established to assess, prevent, coordinate, and manage the risks in different regions 
along the Belt and Road. On the other hand, a legal system for risk prevention of the Belt and Road implementation should be established and improved. For example, the principle of personal jurisdiction in contemporary international law and the Draft Articles on Diplomatic Protection passed by the UN International Law Commission are adopted to formulate Overseas Protection Law of Chinese Citizens. Also, relevant domestic legislation such as the National Defense Law of the People's Republic of China and Gun Control Law of the People's Republic of China should be modified to establish China's own private security company to guard against personal safety risks.

\section{B. Preventing and Settling Disputes for Co-building the Belt and Road}

Contemporary international law provides basic principles, dispute settlement bodies, and specific solutions to prevent and settle various kinds of disputes arising in the process of co-building the Belt and Road.

1. Basic principles. The principles to peacefully settle international disputes are both the basic principles of contemporary international law and international jus cogens. Therefore, the principle of peaceful settlement of international disputes should be complied with to prevent and settle various kinds of disputes regarding the Belt and Road.

2. Dispute settlement bodies. There are a number of organizations established under contemporary international law for the prevention and settlement of various kinds of international disputes in the current international community, such as the International Court of Justice, the Permanent Court of Arbitration, the International Tribunal for the Law of the Sea, the WTO Dispute Settlement Body and some regional international judicial organs. It goes without saying that various kinds of international disputes arising in the process of co-building the Belt and Road can be classified according to their natures and submitted to different judicial bodies for settlement. In particular, according to Opinions on International Commercial Dispute Settlement Mechanisms and Organs in the Belt and Road Construction passed by the Central Leading Group for Comprehensively Continuing Reform in January 2018, ${ }^{56}$ the Supreme People's Court set up "International Commercial Court," "the First International Commercial Court," "the Second International 
Commercial Court" in Shenzhen city and Xi' an city, respectively, to handle crossborder commercial disputes among parties. The fourth court of the Supreme People's Court for Civil Justice is also responsible for coordinating and guiding the work of the two international commercial courts. ${ }^{57}$ It reflects not only the principle of diversified dispute settlement in litigation, mediation, and arbitration, but is also a potentially beneficial attempt for China to establish an international commercial dispute settlement mechanism of the Belt and Road conforming to contemporary international law. ${ }^{58}$

3. Legal and diplomatic solutions. There are two solutions for settling international disputes. One is peaceful settlement, including diplomatic and legal solutions. The other is the use of force, including war and military operations other than war. ${ }^{59}$ As the principle of peaceful settlement of international disputes has become one of the universally recognized basic principles of international law, states are obliged to settle disputes peacefully. Not only diplomatic but also legal solutions can be invoked to settle the disputes arising from co-building the Belt and Road.

\section{International Legal and Institutional Protection of National Interests for Co-building the Belt and Road}

The BRI covers a very large area of cooperation, which includes the transport of oil and gas via pipelines, the establishment of Blue Partnership, the maintenance of sea lane security, and issues closely related to national interests. None of them can be safeguarded by contemporary international law.

1. The international energy law system. The 1994 Energy Charter Treaty provides a legal basis for the smooth transport of oil and gas via pipelines. It covers investment, transport, efficiency, the environment, and the settlement of disputes regarding energy. ${ }^{60}$ Together with the Model Agreement on Intergovernmental Transit Pipeline Transportation of 1999, the Draft Transit Protocol of 2003, the Model Agreement on Transit Pipeline Transportation between Host Governments and Project Investors of 2007, and the International Energy Charter of 2015, the Energy Charter Treaty constitutes the international legal system for energy transit. At present, China has become the largest crude oil importer and has developed many cooperative projects involving oil and gas transportation via pipelines with 
the countries along the Belt and Road. Therefore, the related international legal system for energy transit mentioned above will undoubtedly play an irreplaceable role in ensuring the safe transport of oil via pipelines across northwest, northeast, and southwest China.

2. The international maritime legal system. The United Nations Convention on the Law of the Sea 1982 ("UNCLOS") lays the foundation for the establishment of the Blue Partnership. The UNCLOS, known as the "Constitution for Oceans," only clearly stipulates the legal system in different sea areas, but also serves as the legal basis for global ocean governance and international maritime cooperation. Therefore, the establishment of the Blue Partnership proposed in the BRI shall be undoubtedly supported by the international maritime legal system established by the UNCLOS.

Specifically, the current international community is working on the Code for the Exploitation of International Seabed Area Resources ${ }^{62}$ and the International Agreement on the Conservation and Sustainable Utilization of Marine Biodiversity beyond the National Jurisdiction. ${ }^{63}$ These new emerging standards are not only closely related to the establishment of the Blue Partnership, but also important to China, which is accelerating its establishment as a marine power.

3. Relevant legislation of the United Nations Specialized Agencies. It represented by the International Maritime Organization ("IMO") provides the institutional guarantee for the safety and maintenance of the sea lane security. The South China Sea and the Indian Ocean, through which the 21st Century Maritime Silk Road passes, are areas with a high incidence of piracy and maritime terrorism. Therefore, it is particularly important for China and the countries along the Belt and Road to maintain international cooperation and jointly ensure the safety of the sea lanes. The IMO is not only a UN-specific agency, but also an international organization dedicated to maintaining the safety of the sea lanes. Since its establishment, the International Maritime Organization has been committed itself to maintaining the safety of the sea lanes and has formulated a series of safety and technical regulations, ${ }^{64}$ such as the Preventive Measures against the following: Piracy and Armed Robbery Endangering Ships (1983), Illegal Acts Threatening the Ship Safety and the Security for Passengers and Crew on Board (1985), Illegal 
Acts Endangering Passengers and Crew on Board (1986), the Convention for Stopping Illegal Acts Endangering the Safety of Navigation at Sea (1988), Bill of Amendment of International Convention for the Safety of Life at Sea of 1974 of 2002, and the Protocol of the Convention for Stopping Illegal Acts Endangering the Safety of Navigation at Sea of (2005). The above international legal documents are specially designed to maintain the safety of navigation at sea in a more targeted way than other general conventions on counter-terrorism. They play a very important role in maintaining the safety of maritime energy corridors.

\section{Conclusion}

\section{A. New Trend of International Cooperation in the early 21st Century}

For a long time, international organizations have always been regarded as "a legal form of multilateral cooperation among countries." " However, international organizations are based on the evolution of international relations. The patterns of development of international organizations are not exactly the same; they can take the various trajectories, such as from initial nongovernmental contact to the intergovernmental meetings, from the Europe Concert in the early 19th century to the League of Nations in the first half of the 20th century, from the United Nations coming from the Second World War to the G20 in the 21st century. Nevertheless, G20, as well as the previous "Group of Seven" and the later BRICS, is quite different from the traditional international organizations. None of them has the 'Tripartite Structure' of the traditional international organizations such as the general assembly, the council, and the secretariat. In fact, the G20 without a permanent secretariat was created to deal with the global financial crisis. It is in a loose form, initially a ministerial forum, then gradually upgrading to a multilateral mechanism for consultation on global economic governance at the level a government agency. Similarly, the BRI, as a new type of international cooperation and a new platform for international governance, has flexible, diverse, and elastic cooperative models. It adopts a process of pluralistic and open cooperation rather than prioritizing consistency ${ }^{66}$; each country is devoted to the principles of "joint discussion, co-building, and sharing," using a democratic and transparent decisionmaking process to achieve "diversified, independent, balanced, and sustainable 
cooperation." ${ }^{67}$ Therefore, the BRI continues the new trend of international cooperation in this sense.

\section{B. Declaration of New Round of Reform in the New International Political Order}

In September 2018, an Asia Pacific Security Program of the Center for a New America Security ("CNAS"), an American think-tank clearly pointed out in its issue report, "Power Play: Addressing China's Belt and Road Strategy," that China's Belt and Road Strategy aims to reshape and replace the current international order and international governance system through economic, political, and military means. ${ }^{68}$ Although the report is somewhat exaggerated, it is certain that the BRI inaugurates a procedural change in international, political, and economic order.

On the one hand, the BRI reflects China's responsibility to reform the global governance system. In recent years, as the international situation has become complicated and changeable, the trend against globalization is increasingly prominent; the lack of global governance is worsening, countries are facing increasing challenges, and the role of emerging economies in the global governance is rapidly becoming more prominent. In this regard, China, as the world's second largest economy and the largest developing country, has officially proposed the cooperative initiative to co-build the Belt and Road.

On the other hand, the BRI is gradually shifting from a 'regional initiative' to a 'global initiative.' Due to the openness and inclusiveness of the BRI, China hopes to invite all countries and regions having a common goal to participate in the BRI. Especially after the US withdraws from the Trans-pacific Partnership Agreement, China has embraced Latin America and the Caribbean with open arms, extending the BRI ends to these regions. ${ }^{69}$ Meanwhile, the AIIB initiated and established by China in December 2015 has grown from 57 members in the beginning to 93 countries and regions today.

\section{Beneficial Attempt to Enhance China's International Voice}

First of all, as China's solution to global governance, the BRI enriches the treasure trove of global governance ideas. It reflects that the relationship between China and the world is changing from one-way integration to two-way interaction, from 
'absorption learning' to "cooperation and mutual learning." This shows that China is seeking a shift from the old approach of "seizing opportunities for development" to "creating and sharing opportunities for common development"; China is willing and able to provide a "high value-added" diplomacy. China is not a passive party amid world changes but rather an important participant; it is not only a 'dependent,' but also an 'independent variable.'

Secondly, the BRI has become a popular global public product and international cooperation platform. For example, the AIIB, as an innovative financing mechanism, aims to promote the process of connectivity and economic integration in Asia and strengthens the cooperation between China and other Asian countries. ${ }^{70}$ As a matter of fact, the AIIB is both a rule-maker and rule-follower. The Bank adheres to the existing preferred plan while innovating with respect to multilateral development financing. Most projects of the AIIB are co-financed with the World Bank or the Asian Development Bank. As of May 2018, the AIIB was involved in 26 projects in more than 10 countries. The total loans amount to USD 4.5 billion, covering transport, energy, and sustainable urban projects. ${ }^{71}$

In addition, China contributes USD 40 billion to establish the Silk Road fund to provide financial support for constructing the Belt and Road equally. Its investments include the Karot hydropower station of Pakistan and Yamal liquid natural gas program of Russia. ${ }^{72}$ The BRI is a "global public property" that China can contribute to further integration of the international community.

Finally, China's promotion of the BRI offers a global and multilateral ruling mechanism for the future. Undoubtedly, after over five years since its proposal, the BRI pays attention to the 'soft mechanisms.' These legal documents related to the Belt and Road are initiatives, statements, and memoranda, with weak legal restriction. Such 'soft mechanisms' embody the inclusiveness of the BRI and help to expand its appeal in the beginning stage of the BRI. Nevertheless, the problem of legality must be addressed if the BRI expected to be widely accepted by the parties and gain global recognition as China's solution of global governance,

In the future, both 'hard mechanisms' and cooperative organizations based on international treaties will help to consolidate the rights and obligations of all parties to promote sustainable cooperation under the auspices of China. ${ }^{74}$ 


\section{REFERENCES}

1. See the List of Countries which has Signed Cooperation Documents on Co-building the Belt and Road with China (Apr. 20, 2019), available at https://www.yidaiyilu.gov.cn/ xwzX/roll/77298.htm.

2. $I d$.

3. S.C. Res. 344, U.N. Doc. S/RES/2344(2017), available at http:/www.un.org/en/ga/search/ view_doc.asp?symbol=S/RES/2344(2017).

4. Xi Jinping's Remarks at the Symposium on the 5th Anniversary of Promoting the Belt and Road Construction [习近平在推进 “一带一路” 建设工作5周年座谈会上的讲话] (Aug. 27, 2018). See also Likang Wang, Xi Jinping Talks about the Belt and Road in 2018 [2018年, 习 近平这样谈 “一带一路”], available at http://www.yidaiyilu.gov.cn/xwzx/xgcdt/79168.htm.

5. The National Development and Reform Commission, the Ministry of Foreign Affairs and the Ministry of Commerce, Vision and Action for Co-building the Silk Road Economic Belt and the 21st Century Maritime Silk Road [推动共建丝绸之路经济带和21世纪海上丝绸 之路的愿景与行动] (Mar. 28, 2015), available at http://www.yidaiyilu.gov.cn/wcm.files/ upload/CMSydylgw/201702/201702070519013.pdf.

6. See Leading Group Office of Promoting the Belt and Road Construction, Co-building the Belt and Road: Theory, Practice and China's Contribution [共建 “一带一路”:理念、实践与 中国的贡献] (May 10, 2017), available at http://news.xinhuanet.com/politics/2017- 05/10/ c_1120951683.htm.

7. Supra note 5.

8. Xi Jinping, Opening-up Creates Prosperity, Innovation Leads the Future - Keynote Speech at Opening Plenary of Boao Forum for Asia Annual Conference 2018 [开放共创繁荣、创 新引领未来-在博鳌亚洲论坛 2018年年会开幕式上的主旨演讲] (Apr. 10, 2018), available at http://cpc.people.com.cn/n1/2018/0411/c64094-29918031.html.

9. Supra note 5.

10. Treaty and Law Division of the PRC Ministry of Foreign Affairs, Selected Cases of China’s Practice of International Law [国国际法实践案例选编] 17 (World Affairs Press, 2018).

11. Supra note 5.

12. Supra note 6.

13. Yafei He, China's Diplomacy Promotes a New Pattern of Comprehensive Opening-up [ 中国外交推进全面开放新格局], Reference News [参考消息], Nov. 19, 2018, (12th ed.).

14. Xianghong Zeng, Geopolitical Imagination and Regional Cooperation of the Belt and Road [一带一路” 的地缘政治想象与地区合作], 1 WORLD ECON. \& POLITICS [世界经济与政治] 46-71 (2016).

15. Shin Kawashima, True Competition Begins in the Indo-Pacific, Diplomat, Dec. 24, 2018, available at https://thediplomat.com/2018/12/true-competition-begins-in-the-indo- 
pacific.

16. The National Development and Reform Commission and the State Oceanic Administration, Vision for Maritime Cooperation in the Belt and Road Construction [“一带一路”建设海上 合作设想] (June 20, 2017), available at http://cpc.people.com.cn/n1/2017/0620/c6438729351311.html. It addresses that in addition to the construction of existing corridors, a blue economic corridor connecting Europe through the Arctic Ocean shall be built.

17. China's State Council's Information Office, China's Arctic Policy [中国的北极政策](Jan. 2018). It states: "China stands ready to work with all parties to build 'Polar Silk Road' to promote the opportunities for cooperation in the Arctic brought by the interconnection and interworking and the sustainable economic and social development."

18. China and Panama signed an agreement on the international cooperation in the maritime field in December 2018, hoping to co-develop the maritime transport capacity in the framework of the 21st Century Maritime Silk Road and the maritime transport agreement. See telegram of La Agencia EFE, Dec. 3, 2018, Panama City, quoted from a secondary source of Reference News [参考消息], Dec. 5, 2018 (1st ed.).

19. In June 2015, e.g., Hungary and China signed Memorandum of Understanding between the Government of the People's Republic of China and the Government of Hungary on Co-building the Silk Road Economic Belt and the 21st Century Maritime Silk Road. Hungary is the first European country to sign a cooperation agreement of the Belt and Road with China. In October 2015, South Korea and China also signed Memorandum of Understanding on the Construction of the Silk Road Economic Belt and the 21st Century Maritime Silk Road, and Cooperation on the Eurasian Initiative, which marks the beginning of an organic connection between China's BRI and South Korea's 'Eurasian initiative.'

20. In April 2016, Wang Yi, the Chinese Foreign Minister and Shamshad Akhtar, the Executive Secretary of ESCAP signed "Letter of Intent between Chinese Ministry of Foreign Affairs and ESCAP on Promoting Regional connectivity and the BRI" in Beijing. Both parties will jointly plan specific actions to promote connectivity, the policy connection and pragmatic cooperation of the countries along the BRI. This letter is the first cooperation document of the Belt and Road between China and an international organization setting up a precedent for UN system agencies to directly participate in the construction of the Belt and Road as a significant model.

21. Statement of the Co-Chairs of the Forum on the Belt and Road Legal Cooperation(July 3 , 2018), available at https:/www.fmprc.gov.cn/web/wjbxw_673019/t1573634.shtml

22. Id.

23. Supra note 5

24. Supreme Court of P.R. China, Regulations on Several Issues regarding the Establishment of International Commercial Courts, available at http://www.court.gov.cn/fabuxiangqing-104602.html. 
25. Supra note 5.

26. Supra note 6.

27. 'Six Uniformity' refers to uniform brand logo, uniform transportation organization, uniform whole-course prices, uniform service standard, uniform management team, and uniform coordination platform.

28. Supra note 6.

29. G.A. Res. 62/557, U.N. Doc. A/63/49 (Vol. III), at 106 (Sept. 15, 2008).

30. Agenda 2063, available at file://C:/Users/user/AppData/Local/Microsoft/Windows/ INetCache/IE/4HUAGB07/33126-doc-01_background_note.pdf.

31. According to the Beijing Action Plan passed by China-Africa Cooperation Forum Beijing Summit in 2018, China would work with Africa to implement the 'Eight Actions' of industry promotion, infrastructure connectivity, trade facilitation, green development, capacity building, health and hygiene, cultural and educational exchanges and peace and security, each of which closely connects Agenda 2063. In addition, China and African Union co-compile China-Africa Infrastructure Cooperation Plan to coordinate and promote transnational and trans-regional cooperation projects in Africa.

32. See Leading Group Office of Promoting the Belt and Road Construction, The Belt and Road Initiative: Progress, Contributions and Prospects [共建 “一带一路” 倡议: 进展、贡献 与展望] (Apr. 22, 2019), available at https://www.yidaiyilu.gov.cn/zchj/qwfb/86697.htm.

33. Supra note 6.

34. G. Shayla [ARG], China and Russia Compete for Africa's Resources, BuEnos AIRes ECon. News, Jan. 27, 2019, quoted from Reference News [参考消息], Jan. 28, 2019 (14th ed.).

35. A. Scobell et al., At the Dawn of Belt and Road, China in the Developing World 1 (2018), available at https://www.rand.org/pubs/research_reports/RR2273.html

36. Wenping He, China and Africa Work together to Build a Community with a Shared Future [中国和非洲携手打造 “命运共同体], Reference News [参考消息], Aug. 28, 2018 (11th ed.).

37. Binghua Liu, International Law [国际法](Vol. II), (Piao Guozhe et al. trans. into Chinese) 185 (CUPL Press, 2002).

38. Supra note 32.

39. I. Perez, New Evidence of "Urban Diplomacy" in China's External Action, Observation of China Policy in Spain, Jan. 23, 2019, quoted from Reference News [参考消息], Jan. 25, 2019 (14th ed.).

40. See Our People: Millennium Report of the Secretary General, available at http://www. un.org/chinese/aboutun/prinorgs/ga/millennium/sg/report/sg.htm.

41. Wanqiang Li, The BRI vs Development Inclusive International Law [“一带一路” 倡议与包 容性国际法发展], 5 JiANGXI SOCIAL SCI. [西社会科学] 8 (2017).

42. Yanzhuo Xu, The BRI in 2017: Achievement and Progress, in Global Political and SeCurity Report (2018) 177 (Yuyan Zhang ed., 2018). 
43. Leading Group Office of Promoting the Belt and Road Construction, "The Belt and Road Initiative: Progress, Contributions and Prospects”(April 22, 2019), available at https:// www.yidaiyilu.gov.cn/zchj/qwfb/86697.htm.

44. 'Six Corridors' refers to six major international economic cooperating corridors : The new Eurasia Continental Bridge, the China-Russia-Mongolia Economic Corridor, the China-Central Asia-Western Asia Economic Corridor, the China-Indochina Peninsula Economic Corridor, the China-Pakistan Economic Corridor, and the Bangladesh-ChinaIndia-Myanmar Economic Corridor.

45. 'Six Roads' refers to railway, highway, shipping, aviation, pipeline and space-integrated information network, which are the main components of infrastructure connectivity.

46. See the Leading Group Office of Promoting the Belt and Road Construction, Co-building the Belt and Road: Theory, Practice and China's Contribution (May 10, 2017), available at http://news.xinhuanet.com/politics/2017-05/10/c_1120951683.htm.

47. See Action Plan of Standard Connectivity for Co-building the Belt and Road (2018-20) (Jan. 11, 2018), available at: http://www.yidaiyilu.gov.cn/zchj/qwfb/43480.htm.

48. Supra note 46.

49. D. Kliman \& A. Grace, Power Play: Addressing China's Belt and Road Strategy, Center for a New American Security, Sept. 2018, at 26, available at https://www.cnas.org/ publications/reports/power- play.

50. M. Meidan \& L. Patey, The Challenges Facing China's Belt and Road and Initiative, Danish Institute for International Studies (Mar. 2016), available at file:///C:/Users/user/ AppData/Local/Microsoft/Windows/INetCache/IE/3ILT3G2Q/PB_Belt_and_Road_ WEB.pdf.

51. Supra note 46.

52. Zewei Yang, Risks and Legal Prevention of Building the $21^{\text {st }}$ Century Maritime Silk Road, Global Law Review, No. 1, 2018, pp. 166-168

53. An Chen (ed.), Problems of International Economic Law (Part II, Substantial Content) [国 际经济法学专论 (下编: 分论)] 634-5 (Higher Education Press, 2002).

54. Id. at 657.

55. See List of Agreements on Bilateral Investment Signed by China with Foreign Countries, available at http://tfs.mofcom.gov.cn/article/Nocategory/201111/20111107819474.shtml.

56. The State Administration for Foreign Affairs and Trade (INCOM) opinions on the settlement mechanism and institutions of international commercial disputes on the basis of the establishment of the " establishment of " district " [中办、国办印发《关于建立 “一 带一路” 国际商事争端解决机制和机构的意见》], CCTV NEWs, June 27, 2018, available at http://news.cctv.com/2018/06/27/ARTIKr19Nipd88gasNXGBiUZ180627.shtml.

57. Tong Qi, Study on International Economic and Trade Issues of the Belt and Road [“一带一路”国际经贸法律问题研究] 121-2 (Higher Education Press, 2018).

58. On July 3, 2018, the Commercial Center of Jiangsu Council for the Promotion of 
International Trade successfully mediated a 4-year's long case of pesticide quality dispute between a company in Jiangsu and that in Iran. It is the first international commercial dispute of the Belt and Road which is successfully settled in Jiangsu province. It is the first time to realize the launch of professional mediator list; to invite outsiders to attend the meeting as mediation witnesses; to work with foreign consulates in China for the mediation; and to attempt to launch the arbitration-mediation-connected mechanism.

59. I. Shearer, Starke's International LaW 441-71 (1994).

60. Zhonghong Bai, Study on Dispute Settlement Mechanism by Energy Charter Treaty [<能源宪章条约>争端解决机制研究] 2-3 (Wuhan University Press, 2012).

61. T. Koh, A Constitution for the Oceans, in The Law of the Sea - Official TeXt of the United Nations Convention on the Law of the Sea with Annexes and Index xxiii (1983).

62. Zewei Yang, Formulation of Code for the Exploitation of International Seabed Area Resources and China’s Due Attitude [国际海底区域 “开采法典”的制定与中国的应有立场], 2 Contemp. L. Rev. [当代法学] 26-34 (2018).

63. International Agreement on the Conservation and Sustainable Utilization of Marine Biodiversity beyond the National Jurisdiction is not only one of the most important legislation, but also deemed as the third execution agreement of the United Nations Convention on the Law of the Sea. See Zewei Yang, International Law [国际法] 173 (Higher Education Press, 2017).

64. Zewei Yang ed., Legal safeguard of China’s Maritime Energy Corridor Security [中国 海上能源通道安全的法律保障] 50(Wuhan University Press, 2011).

65. Zewei Yang, Liang Zhu’s International Organization Law (6th ed.) [梁著国际组织法 (第六版)] 3 (Wuhan University Press, 2011).

66. Supra note 5.

67. Supra note 6.

68. Kliman \& Grace, supra note 49.

69. Austria developed a plan of "European Silk Road" in 2018 to connect the industrial centers of Western Europe with the more populous but less developed areas of Eastern Europe. This plan could be undoubtedly connected to China's BRI. See W. Hessel, A Two-way Silk Road, New ZuRICH, Oct. 6, 2018, quoted from Reference News [参考消息], Oct. 9, 2018 (14th ed.).

70. Scobell et al., supra note 34.

71. See 2018 AIIB Annual Report and Financials, available at https://www.aiib.org/en/newsevents/annual-report/2018/_common/pdf/2018-aiib-annual-report-and-financials.pdf. See also supra note 32.

72. Mengzi Fu, Magnificent 5 years of the BRI [“一带一路” 五年历程波澜壮阔], GUANGMING DAILY [光明日报], June 24, 2018.

73. See the report at the website of La Estrella De Panama on December 3, 2018, quoted from Reference News [参考消息], Dec. 5, 2018 (2d ed.). 
74. Some scholar believes that Joint Communique of the Leaders Roundtable of the Belt and Road Forum for International Cooperation 2017 marks that the Belt and Road has evolved from a China's initiative into an international mechanism and agenda, and the role of China has upgraded from the home court, chairman and host to the leading, active and dominant role. See Yanzhuo Xu, The BRI in 2017: Achievement and Progress [2017年 “一带一路” 倡议: 成果与进展], in Global Political ANd Security Report (2018) [全球政治与安全报 告 (2018)] 175 (Yuyan Zhang ed., 2018). 